\title{
O NOVO LEITOR MACHADIANO
}

\section{THE MACHADO DE ASSIS' NEW READER}

\author{
Sílvia Maria Gomes da Conceição Nasser ${ }^{1}$ \\ UNESP - Universidade Estadual Paulista
}

\begin{abstract}
RESUMO: Este trabalho pretende apresentar a imagem do leitor configurada em dois contos de Machado de Assis, "Miss Dollar" e "A chave". Busca-se, a partir da imagem materializada do leitor presente nesses contos, (re)construir seu perfil elaborado no instante da enunciação. O suporte teórico empregado para a conformação do perfil desse leitor é a semiótica greimasiana. Os elementos focalizados na análise dos contos foram as relações estabelecidas no discurso entre enunciação e enunciado e as projeções do enunciatário no enunciado - visto, então, como narratário. Também houve a preocupação de abordar os recursos argumentativos empregados, os temas e as figuras recorrentes e o emprego da intertextualidade como elementos indicadores do perfil desse leitor machadiano.
\end{abstract}

PALAVRAS-CHAVE: Leitor; Machado de Assis; Contos; Semiótica.

\begin{abstract}
This work intends to present the reader's profile of Machado de Assis' two short stories, "Miss Dollar" and "A chave", that present a concrete image of their readers. The theoretical plateau adopted to create the Machado de Assis' short stories reader was based from the Paris School of semiotics. For the analysis of the reading matter, it was chosen the exam of the manifestations of the discourse enunciation, the projection of the enunciator and the enunciate. Also it had the concern to approach the recurrent resources employees, subjects and figures as indicating elements of the profile of the Machado's reader.
\end{abstract}

KEYWORDS: Reader; Machado de Assis; Short stories; Semiotics.

\section{Um encontro com os leitores de Machado de Assis}

BONS DIAS!

Vejam os leitores a diferença que há entre um homem de olho alerta, profundo, sagaz, próprio para

\footnotetext{
${ }^{1}$ Doutoranda do Programa de Pós-Graduação em Lingüística e Língua Portuguesa - UNESP Araraquara
} 
remexer o mais íntimo das consciências (eu, em suma), e o resto da população. Toda a gente contempla a procissão na rua, as bandas $e$ bandeiras, o alvoroço, o tumulto, e aplaude ou censura, segundo é abolicionista ou outra coisa; mas ninguém dá a razão desta ou daquela coisa; ninguém arrancou aos fatos uma significação, e, depois, uma opinião. Creio que fiz verso.

Machado de Assis (2006, v.3, p. 488).

A segunda metade do século XIX - período da produção machadiana - ficou marcada como uma época que não se pode caracterizar de modo fechado, autônomo, porque apresentava concepções de mundo divergentes. Era a passagem de uma estrutura colonial para uma republicana, de uma sociedade escravista e rural para uma sociedade burguesa e urbana. Esse novo painel que começa a se conformar vem pintado com as cores do liberalismo econômico e político, mas ainda apresenta contornos distantes e antigos. Faoro (2006, p. 201) explicita esse contexto no qual as obras ficcionais de Machado de Assis foram produzidas:

A ação, na obra de Machado de Assis, percorre o espaço de cinquenta anos: de 1840 a 1890. Poucos são os episódios da época colonial e raros os acontecimentos da última década do século. [...] Foram cinquenta anos de vibração econômica, da criação dos bancos, das primeiras tentivas industriais, da extinção do tráfico, da abolição, do emprego da mão de obra livre nos campos e nas cidades.

Desde a sua formação, o Brasil estruturou-se numa sociedade rural, constituída de uma aristocracia que empregava a mão de obra escrava para produzir suas riquezas: inicialmente a cana-de-açúcar, depois o café. Paralelamente a essa aristocracia e à massa de escravos, Faoro (2006) afirma que surge uma nova classe social formada por comerciantes e donos de capitais que possibilitavam o estabelecimento desse sistema rural. São responsáveis não só pelo fornecimento de escravos e equipamentos, mas também pela compra da produção. Essa nova classe social engrossará e constituirá a base da sociedade burguesa urbana brasileira.

Enquanto na sociedade colonial a tradição e a origem ilustre garantem o status social elevado, a nova sociedade burguesa que emerge estrutura-se em classes: o dinheiro é a mola impulsora, a garantia da ascensão social. Apesar de se firmar no mais alto nível econômico, a burguesia não domina o campo social, nem detém o poder político, porque a estrutura emergente, apesar de nova, mantém, como resquício de séculos da dominação da nobreza, a mesma concepção de poder: ele sempre estará nas mãos daqueles cujos nascimentos ilustres os tornam legítimos governantes. Resta à burguesia o reconhecimento social, o qual somente consegue ao empregar seu poder econômico na compra de patentes e títulos que, como um verniz, escondem a mácula dessa classe emergente: a sua origem comum. Apesar de rica e depois reconhecida, a burguesia da segunda metade do século XIX ainda não domina nem governa: apoia-se na estrutura tradicional que decide os rumos políticos do Brasil, distribui os cargos e os empregos públicos. Segundo Faoro (2006), há, portanto, duas faixas distintas na ação: a classe burguesa em ascensão, sem autonomia 
política, e a aristocracia, que constitui “[...] o estamento político, que orienta e comanda o Segundo Reinado." (FAORO, 2006, p. 14).

Ainda segundo Faoro (2006), Machado de Assis teria assumido uma nova época, caracterizada pelo tom urbano da sociedade brasileira e pelo fim do sistema escravista e da hegemonia do poder do imperador. Ao conformar a imagem dessa sociedade em transformação em sua obra, estilizou os fatos e os homens, construindo um modelo artificial dessa transição. Isso se justifica não só porque molda um mundo ficcional, mas também pelo fato de que as concepções que regem a sociedade da época são muito divergentes, impossibilitando a construção de um painel que a retrate fielmente.

Sensível a essas transformações, Machado de Assis opta por adequar seus personagens a elas, criando para eles um status intermediário, transitório como a sociedade em que estão inseridos. Na obra machadiana, então, emerge a personagem cujo status não é garantido somente pelo dinheiro. As circunstâncias externas - origem, cunhagem, poder econômico - concorrem para a ascensão social, mas somente a disposição individual marcará o ritmo da escalada social; a ambição e a paixão da personagem são determinantes para o seu reconhecimento. O poder é acessível para aqueles que se dispõem a conquistá-lo. É a ambição que leva o indivíduo à ascensão social e, consequentemente, à busca do poder.

Crítico de sua época, mas principalmente do ser humano, de visão agudíssima, Machado de Assis mostrou, em sua ficção, uma preocupação constante com a configuração da alma humana, evidenciando o paradoxal jogo entre os interesses humanos e as imposições sociais. Isso se evidencia em quase toda a obra que escreveu e publicou em mais de quarenta periódicos existentes no Brasil desde o início de sua carreira na década de 1850: são críticas, crônicas, poemas, contos, romances, peças de teatro, polêmicas, discursos, homenagens e traduções.

Todos os seus contos foram também originalmente publicados em jornais e em revistas, fato que, segundo Gledson (2006), justifica em parte a extensão das histórias, feitas sob medida para o espaço que iriam ocupar, e até mesmo identifica o público para o qual foram escritos. Trinta por cento deles foram aproveitados para a publicação da sua obra definitiva em prosa. O resultado são os sete volumes de contos por ele organizados: Contos fluminenses (1870), Histórias da meia-noite (1873), Papéis avulsos (1882), Histórias sem data (1884), Várias histórias (1895), Páginas recolhidas (1899) e Relíquias da casa velha (1905).

Machado publicou sessenta e três contos no Jornal das Famílias (1863-1878), nos períodos de junho de 1864 a janeiro de 1869 e de junho de 1872 a novembro de 1873 . Dessas histórias, onze foram selecionadas para constituir as duas primeiras coletâneas por ele organizadas: Contos fluminenses, de 1870, e Histórias da meia-noite, de 1873. O Jornal das Famílias era uma publicação ilustrada, recreativa e artística que circulou no Rio de Janeiro na segunda metade do século XIX. Conservadora, inicialmente de tom religioso e moralizador, tinha como alvo a família e destinava várias seções às mulheres, que ali encontravam orientações sobre moda, higiene e culinária. Mas o grande atrativo desse periódico encontrava-se na seção "Romances e Novelas", localizada na parte central do Jornal das Famílias. Ocupando a metade do conteúdo das páginas desse jornal (cerca de trinta, no total), estava destinada à literatura: continha contos, novelas e poesias. Os contos machadianos aí publicados apresentam histórias voltadas para esse público leitor essencialmente feminino e abordam temas como o amor e o casamento, desenvolvidos no contexto ideológico da época, caracterizado pelas rígidas imposições sociais. As narrativas, em sua maioria, giram em torno do amor como força poderosa, único meio de realização e felicidade a quem a ele se submete. 
Para aqueles que não conseguem concretizá-lo por meio do casamento, restam somente o sofrimento e até a morte.

A força positiva do amor é o tema de muitos desses contos publicados no Jornal das Famílias: "Linha reta e linha curva" (1865) - no qual os protagonistas, inicialmente obedientes aos seus propósitos pessoais, negam-se ao amor; este, invencível, conduz os amantes a, enfim, gozarem a plena e real felicidade atingida com o enlace matrimonial -, "As bodas de Luís Duarte" (1873) - que narra o dia do casamento de Luís Duarte e Carlota, desde os preparativos até o final da cerimônia, depois de longo tempo de namoro - e "Ernesto de tal" (1873) - narrativa na qual, após atribulações no namoro, o casamento vem trazer a felicidade ao casal. Como o amor é a única via que conduz à plena e superior realização, aqueles que não o encontram ou estão impossibilitados de realizá-lo sucumbem à decepção, à frustração. Esse destino desastroso é revelado no conto "Frei Simão", de 1864: enganado pela própria família que lhe dissera estar morta a mulher amada, o protagonista faz da própria existência como religioso o seu calvário. Resta-lhe a amargura de nunca ter ao seu lado o verdadeiro amor. Os enredos mudam, mas o tema do amor aliado ao casamento como fator determinante da felicidade é o cerne desses contos publicados no Jornal das Famílias.

Embora Gledson (2006) afirme que Machado de Assis percebeu a dificuldade de dramatizar tensões como a escravidão e o amor entre pessoas de classes sociais diferentes, pois eram tabus fortes para serem discutidos na sociedade brasileira do fim do século XIX, a obra machadiana evidencia um enunciador crítico, consciente da sociedade que retrata e que, na maioria das vezes, emite juízos de valor. Machado não se conformou como um escritor sujeito a esquemas narrativos pré-concebidos, fossem eles românticos ou realistas. Seus contos traçam a trajetória de um autor cuja linguagem aos poucos se vai amalgamando, assumindo uma forma inédita e autônoma. Ao mesmo tempo em que constrói a sua ficção, vai também conformando o seu leitor. Junto com Machado, conduzido pelo braço ou na posição de um observador crítico, esse leitor ideal também evolui - é capaz de realizar uma leitura crítica e reflexiva.

É o que se evidencia em contos como "Luís Soares" (1864), "O segredo de Augusta" (1968), “Aurora sem dia" (1873) e "O relógio de ouro" (1873), todos também publicados no Jornal das famílias. Embora sejam voltados para o público desse periódico, ora abordam temas inusitados, provocadores de reflexão e com tendências críticas à sociedade e ao homem da época, ora exigem do leitor uma postura mais atenta em relação ao esquema narrativo que constrói, repleto de surpresas que se resumem à constante quebra de expectativas criadas pelo próprio narrador, com o intuito de apresentar uma nova configuração para os clichês esquemáticos tão comuns às narrativas seguidoras das tendências literárias daquele momento.

Nesses contos, o amor deixa de ocupar o espaço central para ceder lugar à análise de caracteres humanos e ao enfoque dos problemas sociais. Surgem enredos que abordam temas incomuns e outros até considerados inadequados segundo os conceitos morais da época. A preocupação com a aparência, o valor excessivo dado ao dinheiro, o adultério e o egocentrismo humano desenvolvem-se sutilmente, mas nunca superficialmente nos contos.

Em "Luís Soares" (1864), a convivência em uma sociedade, na qual somente o cumprimento das suas regras garante a sobrevivência física e o reconhecimento social, leva Luís Soares ao suicídio após ter dissipado sua fortuna e ver-se à mercê do desprezo social a que tinha que se submeter. A necessidade de ser destaque em uma sociedade que valoriza os bens materiais e a aparência física é também o tema de "O segredo de Augusta" (1868), que 
mostra a vida de D. Augusta condicionada à sua aparência: o amor à própria beleza levou-a a um egoísmo tal que não aceitava o casamento da filha, temendo a ideia de ser avó e, consequentemente, de envelhecer. Luís Tinoco, de "Aurora sem dia" (1873), crê que a sua existência deve ser grandiosa e, compondo versos, caminharia para o reconhecimento público. Torna-se, mais tarde, deputado conhecido pelos discursos inflamados de imagens e figuras. Em plena câmara, um adversário político ridiculariza seus versos e seu estilo. Incapaz de se projetar socialmente, abandona a política e se afasta do convívio social.

O tema do adultério surpreende e provoca reflexão em "O relógio de ouro" (1873): Luís Negreiros encontra um relógio masculino, que não é seu, em seu quarto. Desconfia de que seja de um provável amante de Clarinha, sua esposa. Tortura-a com palavras, tentando fazê-la confessar a traição. No final, Clarinha lhe mostra o bilhete revelador que acompanhara o relógio quando foi entregue: era um presente de aniversário que a amante de Luís Negreiros lhe enviara.

Essas rápidas referências aos temas desenvolvidos por Machado nesses contos, em sua maioria publicados no Jornal das famílias, revelam um escritor que, ao elaborar suas histórias, desenvolve mecanismos inovadores: ora a abordagem de temas comuns é inusitada, provocando um postura mais reflexiva do leitor, ora a apresentação de problemas sociais e humanos exige criticidade desse leitor. Machado constrói uma narrativa cujo leitor é um parceiro vivaz e apto a julgar ou examinar o homem e a sociedade que, ao longo de sua história, ajudou a construir.

A partir de 1879, Machado de Assis passa a colaborar com A Estação e, em 1881, com a Gazeta de Notícias. Esses dois periódicos apresentam produções machadianas mais arrojadas. A Estação era um jornal ilustrado para a família, mais luxuoso e moderno que o Jornal das Famílias. Publicado quinzenalmente, trazia novidades sobre moda. Apesar de impresso na Alemanha, apresentava um suplemento literário feito no Rio de Janeiro. A colaboração de Machado na Gazeta de Notícias inicia-se em 1881 e se estende ininterruptamente até 1897, “[...] voltando duas vezes em 1899, quatro em 1900, uma em 1902 e outra em 1904." (SOUSA, 1955, p.225). Além das três colunas semanais que assinava - "A Semana", "Bons Dias" e "Balas de Estalo", o escritor publicou também, nesse periódico, quarenta e sete contos.

A Gazeta de Notícias foi o primeiro jornal popular: seus exemplares avulsos eram vendidos nas ruas por garotos-jornaleiros; enquanto os demais, somente por assinatura. Essa iniciativa provocou um aumento expressivo nas vendas. Era especialmente formulado para os letrados da capital federal (enquanto o Brasil apresentava um índice de analfabetismo de 82,3\% em 1872; o Rio de Janeiro, em 1890, tinha aproximadamente 270 mil pessoas $50 \%$ da sua população - capazes de ler e escrever ${ }^{2}$ ) que desejavam literatura amena de romances-folhetins e apreciavam pequenas colunas de crônicas de variedades. Ao mesmo tempo em que consagrava os escritores dando-lhes colunas em suas páginas, a Gazeta de Notícias também se consolidava como um jornal que prezava a literatura: o espaço a ela reservado dava importância ao jornal popular, conferindo-lhe um status elevado, e também material de leitura atraente para a elite letrada.

O espírito liberal de A Estação e da Gazeta de Notícias e de seus novos leitores encontra correspondência em Machado de Assis. Um escritor com abordagens estilísticas e temáticas arrojadas surge no romance Memórias Póstumas de Brás Cubas, em 1881, e, no ano seguinte, na coletânea de contos Papéis Avulsos. Isso se constata no tema

\footnotetext{
${ }^{2}$ Cf. EL FAR, 2004.
} 
predominante nos contos subsequentes: a oposição constante entre os desejos, os sonhos, a vida interior, a essência do ser humano e as regras sociais, o rito claro e público e a aparência. Esse jogo entre a essência do ser humano e as regras impostas pela sociedade resvalam sempre no apagamento do indivíduo e, consequentemente, na sua sujeição às imposições sociais. Segundo Bosi (2003), o sujeito, na obra machadiana, não tem autonomia, para ele é arriscado viver fora das convenções sociais; portanto a única saída para a sobrevivência cotidiana é agarrar-se às instituições sociais que asseguram o pleno direito à vida material e à sua sobrevivência.

O tema fundamental desses contos de Machado de Assis publicados em $A$ Estação e, principalmente, na Gazeta de Notícias não é somente a oposição entre a essência do ser humano e as imposições sociais e a sujeição do indivíduo à coletividade; o ponto nevrálgico de suas narrativas é o questionamento desses valores sociais e das escolhas a que o homem se sujeita.

Nas suas histórias, a sociedade, cujas normas são reguladoras dos relacionamentos e da sobrevivência do homem, impede a realização pessoal. Todas as atitudes humanas voltadas para a concretização de seus desejos são reprimidas porque não valorizam o indivíduo, que é constituído de um caráter frouxo e inconstante porque movido pelos sentimentos. A obediência às imposições da sociedade determina não só a sua sobrevivência, mas também o seu prestígio e o seu reconhecimento social. Desprezar esses valores é sucumbir, é ter ameaçada a vida e ser discriminado.

"Pai contra mãe" - publicado originalmente em Relíquias da casa velha, em 1906 - exemplifica esse poder da sociedade sobre as disposições humanas: Cândido Neves, cujo ofício era pegar escravos fugidos, vê o momento de entregar seu filho à roda dos enjeitados porque não tinha mais meios para sustentá-lo. Depara-se com Arminda, uma escrava fugida. Captura e a entrega ao dono. A escrava, após lutar pela liberdade, cheia de medo e dor, diante de Candinho e do seu senhor, abortou. Ambos, pai e mãe, buscam a realização de seus desejos que se resumem na preservação da família, na garantia da presença e da vida do filho; mas há a diferença social entre eles: ela é cativa; ele, caçador de escravos. Na luta pela sobrevivência, a sobrevida também depende das normas sociais. Vitória de Candinho.

Em "O caso da vara", de 1891, Damião foge do seminário e, por temer a reação do pai, procura a proteção de Sinhá Rita, viúva e suposta amante de João Carneiro, padrinho do seminarista. Ela assume a causa do rapaz, prometendo-lhe resolver o problema. Apela ao amante para que interceda por Damião junto ao compadre, chegando até a lhe enviar um recado afirmando que a manutenção do relacionamento deles dependia da proteção de Damião. Durante todo o dia em que Damião aguarda os reflexos da intervenção da senhora, passa horas agradáveis contando-lhe piadas que faziam rir também Lucrécia, uma escrava ao pé de Sinhá. Ao cair da noite, diante do trabalho não realizado, Sinhá Rita vai castigar Lucrécia com uma vara e pede a Damião que a pegue para ela. Mesmo tendo pensado anteriormente em apadrinhar a escrava, Damião vê-se levado a não interferir no castigo da menina, mesmo diante de seus pedidos desesperados para que a protegesse. Contrariar Sinhá Rita seria arriscar a sua liberdade; por outro lado, a escrava somente sofria porque suas anedotas haviam-na distraído. Na busca pela realização dos seus anseios, Damião, branco e rico, vê as chances de realizá-los ao apoiar as ações violentas da senhora contra sua cria. Esta, escrava, tem a sua vida determinada pelas regras sociais: está sujeita à justiça e aos desmandos de sua senhora. 
A sociedade retratada nos contos publicados na Gazeta pune também aqueles que ameaçam a integridade econômica e moral da família. Na segunda metade do século XIX, os casamentos eram regidos por interesse, portanto as paixões adúlteras encontravam espaço amplo para se abancarem nos corações e nas mentes ociosas femininas. Venancinha, do conto "D. Paula" (1884), desespera-se ao se indispor com o marido Conrado porque flertara com Vasco. Enquanto ameaça às estruturas familiares modelares, o adultério deveria ser punido drasticamente: a separação e a suspeita de traição da esposa eram determinantes para que a mulher fosse desprezada e discriminada pela sociedade da época.

Machado de Assis, ao analisar o ser humano em busca de sua realização interior, revela-nos uma nova faceta dessa luta: como as pessoas sempre buscam a concretização dos seus anseios de modo egoísta, os obstáculos não são somente sociais, são também pessoas que tentam efetivar as próprias vontades, e, portanto, destroem as esperanças das demais. É o que acontece com Vilela, de "A cartomante" (1884). Vivia uma suposta felicidade: ao lado de Rita, sua esposa, sentia-se realizado emocionalmente; com o melhor amigo Camilo dividia seu dia a dia. A descoberta do caso amoroso de Rita com Camilo destruiu-o totalmente, pois a frustração amorosa não encontraria o amigo em quem se apoiar. Foi uma dupla traição. As pessoas que mais amava foram os obstáculos para a sua felicidade. Restou-lhe somente matá-las.

O desejo de o garoto Pilar, em "Conto de escola" (1884), de conseguir sua pratinha vendendo seu conhecimento ao filho do mestre Raimundo, não se realiza: Curvelo, colega de classe, delata-os. Novamente a intervenção de um ser também desejoso do mesmo objeto, ou invejoso daqueles que têm a posse do objeto pretendido, impede a realização plena de outros indivíduos.

O conto "Identidade", de 1887, também aborda a ambição humana refreada pela inveja dos indivíduos. Em vez do convencional início composto de referências temporais e espaciais que antecedem a apresentação das personagens e do enredo, tão comum nos textos folhetinescos da segunda metade do século XIX, começa com um preâmbulo em que o narrador, em tom amistoso, apresenta o tema da semelhança entre pessoas que não têm parentesco:

Convenhamos que o fenômeno da semelhança entre dois indivíduos não parentes é coisa mui rara - talvez ainda mais rara que um mau poeta calado. Pela minha parte não achei nenhum. Tenho visto parecenças curiosas, mas nunca ao ponto de estabelecer identidade entre duas pessoas estranhas. (ASSIS, 2006, v.2, p.1.064).

Descrente da igualdade total entre dois indivíduos de famílias diferentes, o narrador afirma ser esse, portanto, um mote para a narrativa que apresentará, baseada em um papiro de três mil anos encontrado em Tebas. O leitor, preparado para um enredo que foi apresentado como verdadeiro, depara-se com o início típico dos contos fabulares - "Era uma vez" (ASSIS, 2006, v.2, p.1065). Quebra-se, portanto, novamente a expectativa do leitor. Na verdade, o narrador conforma a sua narrativa como mágica por não crer na veracidade de tal história e coloca diante do narratário um enredo cujo tema não é a semelhança física entre pessoas de famílias e castas distintas, como foi proposto, mas a semelhança entre as almas humanas, que se caracterizam pela ambição e pela inveja. Revela-nos a faceta subterrânea dos indivíduos - a sua essência - sempre encoberta pela falsidade de atitudes. Ao constituir sua narrativa como um jogo entre o que vai ser narrado e o que é efetivamente narrado, o narrador 
configura um novo leitor - narratário - que também busca formas inusitadas de expressão do mundo.

Machado construiu uma nova literatura que aborda temas vinculados ao homem e à sociedade de sua época. Mais do que isso, inaugurou entre nós uma prosa que foge aos esquemas artificiais e fantasiosos do melodrama romântico. Seus contos, em sua maioria, são reveladores dessa sua intenção antipassadista: mostram-se avessos à temática e à estrutura narrativa que dominava o ambiente literário brasileiro de sua época.

Ao apontar e demolir os anacronismos da literatura da primeira metade do século XIX, Machado de Assis pretende atrair um público leitor capaz de, simultaneamente, compreender e fruir a literatura inovadora que cria. E o grande responsável pelo envolvimento do leitor nesse seu projeto é o narrador: ao constituí-lo, institui também o leitor que quer atingir, ou configura um leitor afeito ao gosto romântico cujos impulsos interpretativos tenta coibir e sugere um mundo ficcional que se opõe ao artificialismo das narrativas repletas de elementos sentimentais e imaginosos a que esses leitores estavam acostumados.

\section{A conformação de um novo leitor em "Miss Dollar" e "A chave", de Machado de Assis}

A grande função da arte não é dizer o que sempre existiu, mas iluminar a possibilidade de outras existências, sugerir que outras ordens da realidade são possíveis. Por isso, a arte tem sempre um caráter subversivo, mostra-nos que a ordem vigente não é única, não é absoluta, mas é uma entre outras.

José Luiz Fiorin

Ao elaborar seus primeiros contos, Machado de Assis já conhecia seu público: eram consumidores de folhetins românticos, recheados de histórias fantasiosas, personagens idealizadas e temática sentimental vinculada aos valores sociais e religiosos. Ao compor, portanto, suas narrativas, Machado desafia as expectativas desses leitores. Elabora um narrador que nega as inferências do leitor e que as corrige, ao mesmo tempo em que sugere um mundo ficcional que se opõe ao artificialismo das narrativas a que esse público estava acostumado.

É o que se vislumbra em "Miss Dollar" - publicado em Contos fluminenses, em 1870. Ao iniciar a leitura, o leitor depara com uma surpresa: em vez do tom descritivo e romântico, influenciado pelo "hábito de contar pela forma de folhetins" (MATOS, 1939, apud MACHADO DE ASSIS, 2006, v.2, p.12), o narrador apresenta um preâmbulo metalinguístico. Nele afirma que criar expectativa no leitor implica atrair o seu interesse pela leitura. Paradoxalmente, questiona essa maneira folhetinesca de iniciar um relato, recusandoa, pois seria o autor obrigado a longas digressões que somente atrasariam a apresentação dos fatos.

Era conveniente ao romance que o leitor ficasse muito tempo sem saber quem era Miss Dollar. Mas por outro lado, sem a apresentação de Miss Dollar, seria o autor obrigado a longas digressões, que encheriam o papel 
sem adiantar a ação. Não há hesitação possível: vou apresentar-lhes Miss Dollar. (ASSIS, 2006, v.2, p.28).

Estabelece-se, então, o primeiro contrato entre narrador e narratário. $\mathrm{O}$ enredo que pretende construir deverá iniciar-se com a apresentação imediata da personagem que nomeia o conto, Miss Dollar. Curioso, o leitor prossegue a leitura, crente de que, nas próximas linhas, encontrará o perfil da heroína.

Note-se também que, ao referir-se ao estilo composto por digressões que o narrador recusa, há o emprego da embreagem: o narrador refere-se a si mesmo como "autor"; ao enunciatário, como "leitor". Também emprega os verbos no pretérito - "ficasse", "era"- ou no futuro do pretérito - "seria", "encheriam". Tem-se representada a distância que o narrador quer estabelecer desse tipo de estrutura narrativa. Ao empregar, logo em seguida, o verbo no presente do indicativo - "há" - e a locução verbal "vou apresentar" com o valor de futuro, traz a narrativa para o presente dos leitores, a quem se refere por meio do pronome "lhes", representativo da segunda pessoa do discurso. Também o uso da primeira pessoa do singular - (eu) "vou" - dá o tom pessoal na formulação do enredo: será uma história que mostrará imediata e diretamente ao narratário a personagem. É o mecanismo da debreagem enunciativa que proporciona esse sentido subjetivo.

Para a surpresa do leitor - novamente o inesperado -, em vez de Miss Dollar, surgem quatro diferentes imagens da personagem. Todas elas nascem da imaginação dos mais variados leitores, que as conformam de acordo com a sua disposição interior. E todas elas serão negadas, pois a Miss Dollar que nomeia o conto não foi delineada com traços de personalidade de seus leitores. Mais ainda, essas projeções são alvo da crítica e do humor do narrador que constrói caricaturas dessas supostas heroínas, elaborando um caminho sempre oposto ao do narratário, desconstruindo-as, pois suas figuras são ridicularizadas.

A primeira Miss Dollar emerge de uma mente romântica, idealizadora. Ela é poética:

Se o leitor é rapaz e dado ao gênio melancólico, imagina que Miss Dollar é uma inglesa pálida e delgada, escassa de carnes e de sangue, abrindo à flor do rosto dois grandes olhos azuis e sacudindo ao vento umas longas tranças louras. A moça em questão deve ser vaporosa e ideal como uma criação de Shakespeare; deve ser o contraste do roastbeef britânico, com que se alimenta a liberdade do Reino Unido. Uma tal Miss Dollar deve ter o poeta Tennyson de cor e ler Lamartine no original; se souber o português deve deliciar-se com a leitura dos sonetos de Camões ou os Cantos de Gonçalves Dias. O chá e o leite devem ser a alimentação de semelhante criatura, adicionando-se-lhe alguns confeitos e biscoitos para acudir às urgências do estômago. A sua fala deve ser um murmúrio de harpa eólia; o seu amor um desmaio, a sua vida uma contemplação, a sua morte um suspiro. (ASSIS, 2006, v. 2, p. 27).

Nasce da imaginação de um leitor que "é rapaz e dado ao gênio melancólico". A personagem feminina é construída segundo o modelo de heroína que vigorou no Romantismo: pálida, frágil, angelical, para quem o amor é o único e supremo sentimento, pois, segundo supõe o narrador, "deve deliciar-se com a leitura dos sonetos de Camões ou os Cantos de Gonçalves Dias.” Este, poeta da primeira geração romântica brasileira, cujo volume 
citado prefigura, desde o prólogo ${ }^{3}$, a tendência à fantasia, ao sentimentalismo e ao subjetivismo; aquele, autor de sonetos que também tratam do amor como sentimento - contra o qual é impossível lutar - que domina o ser humano. As referências a Shakespeare, a Tennyson e a Lamartine também auxiliam a conformar essa heroína romântica, já que remetem o narratário a figuras idealizadas e à exaltação do sentimento amoroso.

Simultaneamente, esse anjo delineado por uma imaginação exagerada, dominada pela visão idealizadora de mundo do suposto leitor melancólico, desfaz-se no sarcasmo do narrador, que desnuda o ridículo do imaginário romântico, contrapondo a figura etérea da heroína à imagem "do roastbeef britânico, com que se alimenta a liberdade do Reino Unido." E termina sua descrição afirmando: "A figura é poética, mas não é a da heroína do romance."

Em seguida e em oposição ao espírito romântico do primeiro leitor, surge um narratário objetivo e prático para o qual a heroína deveria ser uma mulher de boa saúde e ignorante, talhada pela natureza apenas para gerar filhos robustos e saudáveis. A segunda imagem de heroína que emergirá para, em seguida, ser ridicularizada e negada é a de uma mulher cujos caracteres físicos são valorizados em detrimento dos sentimentos e da inteligência:

Suponhamos que o leitor não é dado a estes devaneios e melancolias; nesse caso imagina uma Miss Dollar totalmente diferente da outra. Desta vez será uma robusta americana, vertendo sangue pelas faces, formas arredondadas, olhos vivos e ardentes, mulher feita, refeita e perfeita. Amiga da boa mesa e do bom copo, esta Miss Dollar preferirá um quarto de carneiro a uma página de Longfellow, coisa naturalíssima quando o estômago reclama, e nunca chegará a compreender a poesia do pôr do sol. Será uma boa mãe de família segundo a doutrina de alguns padres-mestres da civilização, isto é, fecunda e ignorante. (ASSIS, 2006, v.2, p.27)

Essa "robusta americana, vertendo sangue pelas faces, formas arredondadas, olhos vivos e ardentes, mulher feita, refeita e perfeita [...] fecunda e ignorante" também não reflete a personagem que o narrador se propõe a descrever e, portanto, nada tem a ver com o narratário a que o conto se destina.

Também as heroínas construídas nos parágrafos seguintes não serão modelos para Miss Dollar. A terceira a ser apresentada é a figura de uma inglesa rica de cinquenta anos que busca no Brasil material para escrever um romance:

Já não será do mesmo sentir o leitor que tiver passado a segunda mocidade e vir diante de si uma velhice sem recurso. Para esse, a Miss Dollar verdadeiramente digna de ser contada em algumas páginas seria uma boa inglesa de cinquenta anos, dotada com algumas mil libras esterlinas, e que, aportando ao Brasil em procura de assunto para escrever um romance, realizasse um romance verdadeiro, casando com o leitor aludido. Uma tal Miss Dollar seria incompleta se não tivesse óculos verdes e um grande cacho de cabelo grisalho em cada fonte. Luvas de renda branca e chapéu de

\footnotetext{
${ }^{3}$ Em Primeiros cantos (1969), Gonçalves Dias afirma no prólogo que buscou "Casar [...] o pensamento com o sentimento - o coração com o entendimento - as ideias com a paixão - cobrir tudo isto com a imaginação, fundir tudo isto com a vida e com a natureza, purificar tudo com o sentimento da religião e da divindade [...]."
} 
linho em forma de cuia seriam a última demão deste magnífico tipo de ultramar. (ASSIS, 2006, v. 2, p.27-28).

Descrita fisicamente como a típica senhora inglesa - "Uma tal Miss Dollar seria incompleta se não tivesse óculos verdes e um grande cacho de cabelo grisalho em cada fonte. Luvas de renda branca e chapéu de linho em forma de cuia seriam a última demão deste magnífico tipo de ultramar." -, povoa o imaginário do leitor brasileiro "que tiver passado a segunda mocidade e vir diante de si uma velhice sem recurso." Há nesse trecho uma crítica mordaz ao casamento com uma mulher rica, configurando-o o mais seguro benefício com o qual se pode contar. Procedimento recorrente nos folhetins, o enriquecimento rápido e inesperado que vem por meio de herança ou casamento é mais um clichê romântico que o narrador pretende desvelar.

A última figura a ser descartada nasce da imaginação de um leitor, comparativamente aos anteriores, mais sagaz - segundo o julgamento do próprio narrador que vê no nome estrangeiro uma indicação do status social da personagem: nem inglesa, nem americana, nem romântica, mas rica e brasileira. É o protótipo da mulher que povoa os salões burgueses das narrativas urbanas românticas: "Mais esperto, que os outros, acode um leitor dizendo que a heroína do romance não é nem foi inglesa, mas brasileira dos quatro costados, e que o nome Miss Dollar quer dizer simplesmente que a rapariga é rica.” (ASSIS, 2006, v. 2, p. 28).

Após a apresentação do rol de prováveis personagens que o narrador desconsiderou, vem a surpresa que consiste na dupla ruptura do contrato referente à apresentação da personagem principal: não é feita diretamente e Miss Dollar não é uma típica heroína:

A descoberta seria excelente se fosse exata; infelizmente nem esta nem as outras são exatas. A Miss Dollar do romance não é a menina romântica, nem a mulher robusta, nem a velha literata, nem a brasileira rica. Falha desta vez a proverbial perspicácia dos leitores; Miss Dollar é uma cadelinha galga. (ASSIS, 2006, v.2, p.28).

O narrador, que inicialmente propôs apresentar de imediato a personagem, oferece ao narratário as digressões que primeiramente negara. É o recurso da preterição: no começo do conto, afirma que não irá adiar a apresentação da personagem principal, criando, assim uma expectativa de que a descrição da heroína virá em seguida; mas, em vez da imagem da personagem, vem uma enumeração de prováveis figuras, as quais são descartadas por não corresponderem à personagem do conto. Em vez da apresentação direta de Miss Dollar, o que se tem é um estilo repleto de desvios. Estes constituem um recurso que gera expectativa no leitor a respeito da imagem de Miss Dollar que será construída, uma vez que nenhum dos perfis convencionais serve para descrevê-la.

Ao elaborar, finalmente, a figura da personagem principal, dá ao leitor uma cadelinha - ser pouco adequado, segundo os padrões românticos da época, para assumir a personagem que nomeia uma narrativa folhetinesca. Isso implica um novo fazer persuasivo do narrador: Miss Dollar terá de se justificar com heroína do conto. Assim se inicia efetivamente a narrativa. Miss Dollar teve seu nome nas colunas de dois grandes jornais da época associado a uma promessa de uma boa recompensa para quem a devolvesse ao seu legítimo dono. Isso a tornou o alvo de inúmeras pessoas que nela viam a possibilidade de ganho fácil de dinheiro. 
Novamente a zombaria toma corpo: o narrador descreve a cadelinha sumariamente, reproduzindo o anúncio em que figura o seu desaparecimento:

Desencaminhou-se uma cadelinha galga, na noite de ontem, 30. Acode ao nome de Miss Dollar. Quem a achou e quiser levar à Rua de Mata-cavalos $\mathrm{n}^{\circ} \ldots$, receberá duzentos mil-réis de recompensa. Miss Dollar tem uma coleira ao pescoço fechada por um cadeado em que se leem as seguintes palavras: De tout mon coeur. (ASSIS, 2006, v.2, p.27).

Miss Dollar, inicialmente, é apresentada como heroína; mas, ao ser retratada como uma cadelinha galga, essa imagem se desfaz, pois não está de acordo com a de uma típica personagem romanesca. Seu perfil constrói-se, portanto, sobre uma oposição. Essa diferença é o fundamento da categoria semântica /ser/ versus /parecer/, constituinte da Semântica do nível fundamental do percurso gerativo de sentido. Essa oposição pode ser apreendida conjuntamente já que os dois termos têm um traço comum. No caso de Miss Dollar, tanto /ser/ quanto /parecer/ situam-se no domínio da /existência/. Esses termos opostos mantêm entre si uma relação de contrariedade e são denominados termos contrários. O termo /ser/ pressupõe o termo /parecer/ para ganhar sentido e vice-versa. Se se nega cada um dos contrários, obtêm-se os contraditórios: /não ser/ é o contraditório de /ser/ e /não parecer/ é o de /parecer/. Os dois contraditórios - /não ser/ e /não parecer/ - são também contrários entre si (subcontrários).

Na Sintaxe do nível fundamental, há duas operações: a afirmação e a negação. Delas podem aparecer as seguintes relações, dadas as categorias /ser/ versus /parecer/: afirmase /ser/, nega-se /ser/, afirma-se /parecer/; ou afirma-se /parecer/, nega-se /parecer/, afirma-se /ser/.

A oposição /ser/ versus /parecer/ constitui a categoria semântica também do discurso do narrador. Ao propor um contrato que não cumpre, o narrador estabelece um novo sentido para a relação entre narrador e narratário. Aquilo que "parece" não "é". O que aparentava ser - /parecer/ - uma narrativa direta, sem longas digressões transformou-se em um texto repleto de desvios e esvaziamentos de expectativas - /não ser/. Essa nova forma de narrar não significa que o narrador institui uma "mentira" (/parecer/ e /não ser/), mas que a estrutura narrativa que propõe foge aos esquemas modelares da época. Exige, então, um narratário capaz de lidar com "surpresas", que seja mais ágil e preparado para ler um texto que não o guia pelos sentidos, mas que o convida a desvendar esses sentidos. $\mathrm{O}$ narrador, sagaz e astuto, assume uma postura crítica frente às estruturas narrativas convencionais. Reconhece-as artificiais e inúteis. Desse modo, também está configurando um leitor que o acompanha nessa crítica, à medida que o convoca a observar os recursos que emprega. Desse modo, o narratário participa do processo de construção de uma nova literatura que foge aos procedimentos românticos.

O narrador, desde o início da apresentação da primeira suposta heroína, evidencia a distância que há entre o leitor que configura e aquele já amalgamado pelos esquemas comuns à literatura folhetinesca. Ao se referir a todos os leitores que são descartados, emprega o mecanismo da debreagem enunciva novamente - cada um dos narratários é tratado como "leitor". O narrador caracteriza-os como tipos superficiais e previsíveis. Descarta-os durante toda a narrativa, tratando-os ora como "leitor superficial", ora como "leitor grave", ou até mesmo afirmando terem eles "pouca prática de mundo" (ASSIS, 2006, v.2, p.32). 
O objetivo desse narrador é levar o enunciatário a identificar a impropriedade desses recursos Para isso nega as estruturas românticas, ridicularizando-as, como fez com as imagens inventariadas de Miss Dollar.

Não só os mecanismos argumentativos e a debreagem configuram o leitor de "Miss Dollar". A abordagem inovadora da temática da realização amorosa também seleciona esse narratário. Ao contrário do enredo convencional, ele questiona ser o amor um sentimento puro que, concretizado pelo matrimônio, pode proporcionar a verdadeira felicidade.

Margarida, para quem o amor tinha esse significado, experimentara a infelicidade no casamento. Entregara-se, apaixonada, a um marido que vira, no matrimônio, somente a oportunidade de gozar a vida usufruindo da riqueza dela. Viúva e rica, adquiriu a certeza de que nunca seria realmente correspondida em seus sentimentos, porque haveria sempre seus cabedais atraindo aqueles que viam no casamento um negócio.

Emerge a crítica à sociedade da época, para a qual o interesse econômico se sobrepõe a qualquer sentimento humano. As leis sociais asseguram a sobrevivência física e o reconhecimento social àqueles que possuem riqueza. Os desejos, os anseios, enfim o interior do ser humano deve-se sujeitar a essas regras. É a oposição fundamental: essência versus aparência. Esta se refere às normas do grupo social que uniformizam as atitudes humanas; aquela é a espontaneidade das pessoas, seus traços próprios, os seus desejos, a sua independência.

Margarida opõe-se à visão materialista e interesseira dos relacionamentos. Sofrera com a vaidade de seu finado esposo, logo vê em cada pretendente um grande interesseiro prestes a lhe abocanhar a fortuna e a fazê-la sofrer. Assim, ao conhecer o Dr. Mendonça, que lhe restitui Miss Dollar e passa a cortejá-la, mostra-se indiferente. Mas a insistência do médico a conquista. Margarida enfim o ama, trata-o com meiguice, mas se mostra avessa ao relacionamento. É penoso para ela ver-se novamente alvo do interesse pecuniário de mais um pretendente por quem ela nutria o mais puro sentimento. Obriga a si mesma a distanciar-se dele e marca uma viagem de alguns meses para o interior do Rio de Janeiro. Seria tempo suficiente para esfriar seus sentimentos.

Às vésperas da partida, recebe uma visita inesperada. À noite, sem ser visto, Mendonça entra na casa de dona Antônia, tia de Margarida com quem esta morava, e dirige-se ao quarto da moça. Chocada com a audácia do médico, exige dele uma reparação. Assim se realiza o casamento, que não passou de uma celebração de um acordo segundo o qual o noivo se propôs a salvar a reputação da noiva, sem dela exigir a realização efetiva dos contratos matrimoniais. Margarida novamente é prisioneira das regras sociais e, por isso, infeliz. Amava Mendonça, mas os laços do matrimônio não selaram a sua felicidade. Foram, antes, um arranjo que lhe garantira a integridade moral perante a sociedade. Novamente o leitor acostumado às narrativas em que o amor se concretiza com a aprovação da sociedade - topa com uma realidade ficcional distinta: os conceitos morais que antes constituíam os maiores obstáculos à realização do amor cedem espaço a impedimentos que estão na natureza psíquica, na alma da personagem.

Também as manifestações do amor fogem ao tom passional dos folhetins da época. O que se vê em Margarida e em Dr. Mendonça é a ausência das manifestações tempestuosas desse sentimento. O tempo assume, então, o importante papel de mostrar a Margarida que suas suspeitas eram gratuitas. Mendonça mostrara-se íntegro, honesto e a respeitara. O casamento efetiva-se. Triunfo do amor.

É a repetição da consagrada fórmula folhetinesca que Machado de Assis desenvolve, mas com elementos que a distinguem da narrativa tradicional. Em "Miss Dollar", 
toma vulto a oposição entre o mundo interior do ser humano, a sua individualidade e a sociedade e suas normas uniformizadoras. Essa oposição é índice de que o narrador busca analisar a problemática existência humana, e não simplesmente desenvolver uma narrativa que aborde a temática amorosa segundo os modelos ficcionais da época.

O enunciatário a quem o enunciador se dirige, portanto, deve ser capaz de analisar e reconhecer os sentimentos humanos não somente como molas propulsoras das atitudes individuais, mas sujeitos também às determinações sociais. Logo é um leitor que não se convence da existência calcada apenas nos desejos, nem nas regras impostas, deve ser crítico da condição humana representada, na ficção, pelas personagens que transitam entre a essência e a aparência. Sem esta não sobrevivem na sociedade; sem aquela não se realizam como indivíduo.

"Miss Dollar" está construído para um leitor capaz de perceber as dissimulações presentes no discurso do narrador. Também questionador, requer do narrador um esforço para persuadi-lo de certas escolhas, pois não se deixa seduzir por afirmações superficiais e não aceita passivamente as imposições. Ao realizar o seu discurso, o enunciador de "Miss Dollar" busca um enunciatário que também esteja disposto a romper com as convenções das narrativas tradicionais, que seja crítico e capaz de refletir não só sobre as circunstâncias nas quais se instauram a problemática humana, mas principalmente sobre a estrutura narrativa inovadora que, ao seu lado, ajuda a construir.

Mas o leitor de "Miss Dollar" também pode ser outro, afeito ao repertório da literatura sentimental. Nesse caso, o narrador não vai de encontro a ele; ao contrário, simula aplicar os procedimentos românticos à narrativa - aparentemente compartilha o mesmo inventário romanesco - para, em seguida, demonstrar que são inaplicáveis e inviáveis. Concebe, assim, o leitor que quer ter como parceiro na elaboração da nova literatura que amalgama nos seus contos.

Esse narratário que vai sendo forjado ao longo da narrativa emerge do enunciado e revela-se extremamente culto. É consumidor dos contos de Machado de Assis e também da obra de Shakespeare, Gonçalves Dias, Camões, entre outros citados no decorrer da narrativa, além de leitor de grandes jornais brasileiros da época: "Uma tal Miss Dollar deve ter o poeta Tennyson de cor e ler Lamartine no original; se souber o português deve deliciarse com a leitura dos sonetos de Camões ou os Cantos de Gonçalves Dias." (ASSIS, 2006, p. 27) ; "O Jornal do Comércio e o Correio Mercantil publicaram nas colunas dos anúncios as seguintes linhas reverberantes de promessa [...]" (ASSIS, 2006, p. 28). Essas constantes citações exemplificam o emprego da intertextualidade para conformar o leitor machadiano.

O diálogo metalinguístico entre narrador e narratário e também a inserção de outras realidades ficcionais, que não as romanescas, constituem recursos que instituem um novo leitor para a literatura que Machado inaugura. Esses elementos estão presentes também em "A chave", publicado entre 1879 e 1880 no periódico A Estação.

No primeiro parágrafo do conto, como ocorre também no início de "Miss Dollar", entabula-se uma discussão a respeito do modo mais conveniente de iniciar uma narrativa ficcional. Um estilo direto e simples seria o melhor não só para o narrador, mas também para o leitor.

Não sei se lhes diga simplesmente que era de madrugada, ou se comece num tom mais poético: a aurora, com seus róseos dedos... A maneira mais simples é o que melhor me conviria a mim, ao leitor, aos banhistas que estão agora na Praia do Flamengo, - agora, isto é, no dia 7 de outubro de 
1861, que é quando tem princípio este caso que lhes vou contar. Convinhanos isto; mas há lá um certo velho, que me não leria, se eu me limitasse a dizer que vinha nascendo a madrugada, um velho que... Digamos quem era o velho. (ASSIS, 2006, v.2, p. 871).

Ao empregar a primeira pessoa e dirigir-se aos leitores como segunda pessoa (o pronome "lhes", apesar de referir-se à terceira pessoa gramatical, vem indicando o interlocutor) - "Não sei se lhes diga" -, o narrador obtém, com o mecanismo da debreagem enunciativa, um efeito de subjetividade e uma seleção de seu leitor: é aquele que, como o narrador, prefere a narração objetiva, livre de figuras embelezadoras da realidade ficcional.

Apesar de conveniente à maioria dos leitores que buscam uma narrativa direta, livre de digressões e de adjetivações excessivas, o texto enxuto não seria lido por um leitor que o narrador denomina, inicialmente, "um certo velho". Ele é, na verdade, o Major Caldas, primeira personagem do conto a surgir. Na sua descrição, há uma crítica explícita a uma literatura construída sobre a valorização das formas consagradas tão prezadas pela personagem:

Imaginem os leitores um sujeito gordo, não muito gordo, - calvo, de óculos, tranquilo, tardo, meditativo. [...] disse já que era calvo; equivale a dizer que não usava cabeleira. Incidente sem valor, observará a leitora, que tem pressa. Ao que lhe replico que o incidente é grave, muito grave, extraordinariamente grave. A cabeleira deveria ser o natural apêndice da cabeça do Major Caldas, porque cabeleira traz ele no espírito, que também é calvo.

Calvo é o espírito. O Major Caldas cultivou as letras, desde 1821 até 1840, com um ardor verdadeiramente deplorável. Era poeta; compunha versos com presteza, retumbantes, cheios de adjetivos, cada qual mais calvo do que ele tinha de ficar em 1861. A primeira poesia foi dedicada a não sei que poeta, e continha em gérmen todas as odes e glosas que ele havia de produzir. (ASSIS, 2006, v. 2, p.871).

O narrador chama a esse estilo de "calvo", já que infecundo; compara-o à calvície real do major, como se referindo ao raso raciocínio da personagem, incapaz de reconhecer como literário outro estilo que não fosse a reprodução das fórmulas literárias do passado. A crítica a esse tipo de literatura e a seus respectivos leitores torna-se risível:

Não compreendeu nunca o Major Caldas que se pudesse fazer outra coisa que não glosas e odes de toda a casta, pindáricas ou horacianas, e também idílios piscatóricos, obras perfeitamente legítimas na aurora literária do major. Nunca para ele houve poesia que pudesse competir com a de um Dinis ou Pimentel Maldonado ${ }^{4}$, era a sua cabeleira de espírito. (ASSIS, 2006, v.2, p. 871).

Apesar de afirmar que o estilo direto seria o preferido, o narrador segue abordando o próprio fazer literário como tema, em vez de flagrar e expor as ações que

\footnotetext{
${ }^{4}$ Antônio Dinis da Cruz e Silva (1731-1799) e João Vicente Pimentel Maldonado (1773-1838) são poetas do Arcadismo português. Este foi autor de variados madrigais e anacreônticas. Aquele, à semelhança de Ovídio, compôs doze Metamorfoses, nas quais mitifica a natureza brasileira.
} 
constituem o enredo. A figura do major não remete a um espaço ficcional externo; sua caracterização é uma maneira de o narrador voltar o texto para si mesmo, para a sua materialidade.

Ao criticar e ridicularizar o estilo amalgamado na herança neoclássica e questionar a literatura alicerçada em imagens forjadas por figuras idealizadoras, o narrador leva o narratário a crer que sua narrativa será, efetivamente, fluida, enxuta e, portanto, inovadora. Mas o narratário, que está à espera de um enredo que lhe revele instantaneamente os seus elementos, somente encontra essas digressões que adiam a sua apresentação. É a preterição: o narrador opta por um estilo sem rodeios; mas, em vez de colocá-lo em prática, torna seu texto digressivo ao ceder o espaço ficcional à abordagem metalinguística. Reside nesse recurso a crítica aos enredos marcados pelo exagero na caracterização das cenas.

O narrador volta a abordar a expectativa do Major Caldas quanto ao estilo elaborado de modo exagerado; mas, para a surpresa do narratário, em vez do desprezo, encontra o narrador preocupado com os argumentos que validam esse mesmo estilo superficial:

Ora, é certo que o Major Caldas, se eu dissesse que era de madrugada, darme-ia um muxoxo ou franziria a testa com desdém. - Madrugada! era de madrugada! murmuraria ele. Isto aí diz qualquer preta: - "nhã-nhã, era de madrugada..." Os jornais não dizem de outro modo; mas uma novela... (ASSIS, 2006, v. 2, p.872).

O major afirma que a ausência desse estilo rebuscado descategoriza o texto, pois o aproxima da redação jornalística e, pior, assemelha-se à fala de uma escrava: "Isto diz aí qualquer preta: nhã-nhã, era de madrugada [...]". O narrador parece sucumbir ao raciocínio dessa personagem e inicia um relato marcado pelo estilo que negara até então:

Vá, pois! A aurora, com seus dedos cor-de-rosa vinha rompendo as cortinas do oriente, quando Marcelina levantou a cortina da barraca. A porta da barraca olhava justamente para o oriente, de modo que não há inverossimilhança em lhes dizer que essas duas auroras se contemplaram por um minuto. (ASSIS, 2006, v.2, p. 872).

Na verdade, o objetivo é mostrar que o conceito de literatura restringia-se a uma forma artificial de expressão que o narrador nega. Isso vem explícito no comentário seguinte:

[...] Um poeta arcádico chegaria a insinuar que a aurora celeste enrubesceu de despeito e raiva. Seria porém levar a poesia muito longe.

Deixemos a do céu e venhamos à da terra. Lá está ela, à porta da barraca com as mãos cruzadas no peito, como quem tem frio; traja a roupa usual das banhistas, roupa que só dá elegância a quem já a tiver em subido grau. É o nosso caso. (ASSIS, 2006, v.2, p.872).

Dirige-se a um narratário acostumado às convenções das narrativas tradicionais. Quer reelaborar esse gosto e iniciar um processo de formação de um leitor mais afeito a uma literatura que não sucumba a normas pré-concebidas. Para isso, o narrador destinador - procura persuadir o narratário - seu destinatário - de que o estilo que inaugura parece e é o mais adequado, porque livre de exageros. Seu objetivo é convencer o leitor de 
que esse modo nutrido de narrar é artificial, por meio da comparação entre o que o narrador lhe apresenta com aquilo que ele já conhece e com aquilo em que crê.

Em muitas passagens, o narrador constrói cenas e comentários como se fosse o major a elaborá-las. Emprega o tom jocoso a fim de ridicularizar o estilo que combate. É o que se observa na passagem em que descreve o mar: "Da praia, alguns olhos, puramente curiosos, se estendiam aos banhistas ou cismavam puramente contemplando o espetáculo das ondas que se dobravam e desdobravam, - ou como diria o Major Caldas - as convulsões de Anfitrite." (ASSIS, 2006, v.2, p.873). Também após a descrição de Luís Bastinhos, personagem do conto, surge o comentário: "O Major Caldas, se os observasse, era capaz de casá-los, só para ter o gosto de dizer que unia uma náiade a um tritão.”(ASSIS, 2006, v.2, p. 874). Novamente, ao fazer referência ao desejo do major de casar a filha com Luís Bastinhos, o narrador afirma: "[...] uni-los pelos 'doces laços do himeneu', que todas foram as suas próprias expressões mentais." (ASSIS, 2006, v.2, p. 880). Ao empregar "Anfitrite”, "náiade”, "tritão" e "himeneu", remete o narratário aos elementos da mitologia, mas com a intenção de criticar o estilo que deles faz uso. Ao mesmo tempo em que propõe uma narrativa direta, sem digressões ou imagens desgastadas e em excesso, o narrador delas faz uso para apontá-las inviáveis. Busca, nessa oposição, refinar o gosto do leitor que pretende ter como parceiro do estilo que inaugura.

Esse propósito também norteia o tema que desenvolve nesse conto. Aparentemente constrói uma ficção modelada pela felicidade condicionada à realização sentimental, mas a oposição entre ser e parecer emerge no conto. A narração parece abordar uma história moldada nos cânones românticos, porém é uma crítica aos laços construídos sobre a superficialidade das relações humanas. Assim, "A chave" narra o encontro de Marcelina e Luís Bastinhos na Praia do Flamengo. Este, na primeira vez que vê Marcelina, sente-se atraído; aquela desenvolve uma antipatia imediata por ele. Moça voluntariosa, arrisca-se nadando em mar agitado e acaba sendo salva justamente por Luís. Após alguma resistência de Marcelina, o casamento entre eles se realiza. Triunfo do amor.

Simultaneamente às peripécias que adiam a concretização do amor - Marcelina não demonstra querer Luís Bastinhos por acreditar que ele não a faria feliz, pois não tem a chave de seu coração (referência explícita ao título por meio de uma expressão desgastada) -, o narrador vai elaborando uma narrativa arrojada, que aprecia negativamente esse estilo romanesco de que faz uso. É dessa forma que quer conquistar o novo leitor: atraí-lo com elementos por ele conhecidos, mostrar-lhe a inconveniência desses mesmos ingredientes e apresentar-lhe uma forma inovadora de expressão, reformando o seu gosto.

Aparentemente Luís Bastinhos era o esposo ideal, mas não para Marcelina, que busca nos pretendentes qualidades que despertem nela e na sociedade a admiração. Quando Luís revela-se um exímio valsista, imediatamente sente atração por aquele que é disputado no salão. A personagem feminina é superficial, pois os parâmetros para a escolha do esposo repousam somente na aparência: apesar de lhe ter salvado a vida, Luís pareceu-lhe sem graça, insosso; somente tem olhos para ele quando os olhares de outras pessoas também se voltam para ele. $\mathrm{O}$ valor que lhe dá vem com o valor que os outros lhe dão. Ao encerrar o conto, o narrador não deixa de dar seu parecer desfavorável a essa atitude de Marcelina: em tom ácido, afirma ter sido a coreografia, mas não a gratidão, a chave do coração da moça.

O enredo de "A chave" é calcado na crítica aos elementos romanescos. Por isso também as descrições das personagens que compõem o par amoroso fogem aos modelos idealizados e angelicais. Empenhado em garantir um status verossímil à narração, o narrador, 
ao compor o retrato de Marcelina, faz referência à claridade da manhã para poder, juntamente com o leitor, visualizá-la e elaborar o seu perfil:

Agora que a luz está mais clara, podemos ver bem a expressão do rosto. É uma expressão singular de pomba e gato, de mimo e desconfiança. Há olhares dela que atraem, outros que distanciam, - uns que inundam a gente como bálsamo, outros que penetram como uma lâmina. (ASSIS, 2006, v.2, p. 872).

O mecanismo da debreagem enunciativa temporal - o emprego do advérbio "agora" e do presente do indicativo "está" - e actancial - a primeira pessoa do plural da forma verbal "podemos" - instaura o narrador e o narratário na cena como testemunhas oculares. Ao colocar o narratário em cena, o narrador cria uma cumplicidade com o leitor. Enquanto este tem a impressão de ver a personagem por si mesmo, na verdade, é aquele que o conduz à elaboração dessa imagem. Assim instaura no narratário o ponto de vista que quer: em um estilo direto e objetivo, o narrador caracteriza Marcelina não como uma heroína idealizada com ar angelical, mas como uma personagem marcadamente bela e sensual, de gênio alternadamente dócil e desconfiado.

A insistência do narrador em abordar a estrutura narrativa revela a preocupação em relação à maneira singular de exprimir-se, que se contrapõe à tendência romanesca. A metalinguagem, portanto, emerge constantemente para adaptar o narratário a esse modo de expressão do narrador. No início do capítulo III, aponta, no próprio texto, lances romanescos para, logo em seguida, descaracterizá-los como tais:

$\mathrm{Na}$ verdade, se a leitora gosta de lances romanescos, aí fica um, com todo o valor das antigas novelas, e pode ser também que dos dramalhões antigos. Nada falta: o mar, o perigo, uma dama que se afoga, um desconhecido que a salva, um pai que passa da extrema aflição ao mais doce prazer da vida; eis aí com que marchar cerradamente a cinco atos maçudos e sangrentos, rematando tudo com a morte ou a loucura da heroína.

Não temos cá nem uma coisa nem outra. A nossa Marcelina não morreu nem morre, doida pode ser que já fosse, mas de uma doidice branda, a doidice das moças em flor. (ASSIS, 2006, v.2, p. 875).

Para persuadir o leitor de que esses elementos fantasiosos em nada colaboram para a expressão literária que formula, emprega a embreagem. Ao se dirigir ao narratário, chama-o de "leitora", não o trata como a segunda pessoa, estabelecendo uma distância entre ambos. Isso evidencia que o narratário que quer modelar afasta-se daquele afeiçoado ao enredo imaginoso da literatura romântica. Esta vem figurativizada pelos elementos "lances romanescos", "antigas novelas", "dramalhões antigos", "aflição", "atos maçudos e sangrentos", "morte ou a loucura" e "heroína", que conformam o tom maravilhoso que o narrador, em seguida, despreza. É interessante notar que, ao figurativizar essa estrutura, o narrador emprega o adjetivo "antigo" por duas vezes - "antigas novelas" e "dramalhões antigos" -, externando a sua desaprovação a essa tendência.

Ao revelar, logo em seguida, o desprezo pelos elementos arrolados, o narrador emprega a debreagem enunciativa - temporal: "temos" e actancial: "nossa". Esse recurso provoca uma aproximação entre o narrador que propõe essa forma inovadora e o narratário. Esse tom marcadamente inovador surge também no início do capítulo seguinte: 
Saiamos do mar que é tempo. A leitora pode desconfiar que a intenção do autor é fazer um conto marítimo, a ponto de casar os dois heróis nos próprios "paços de Anfitrite", como diria o Major Caldas. Não; saiamos do mar. Já tens muita água, boa Marcelina. Too much of water hast thou, poor Ophelia! A diferença é que a pobre Ofélia lá ficou, ao passo que tu sais sã e salva, com a roupa de banho pegada ao corpo, um corpo grego, por Deus! E entras na barraca, e se alguma coisa ouves, não são lágrimas dos teus, são os resmungos do major. Saiamos do mar. (ASSIS, 2006, v.2, p.877).

Dos seis capítulos que compõem o conto, os três primeiros situam as personagens no mar, na Praia do Flamengo. O excerto acima inicia a sequência dos três últimos capítulos nos quais a ação se transfere do ambiente marítimo para o urbano. Ao empregar a debreagem enunciativa - o imperativo e a primeira pessoa do plural: "Saiamos"-, o narrador praticamente ordena que o narratário o acompanhe no deslocamento espacial que propõe para a narrativa, pois se nega a elaborar um discurso idealista da felicidade dos amantes no mar e também não pretende transformá-lo em uma tragédia ao estilo de Hamlet, de William Shakespeare ${ }^{5}$. Ao distanciar o percurso da personagem Marcelina desses dois modelos, o narrador emprega "leitora" para designar o narratário e, para si, "autor". O recurso da embreagem provoca o efeito de afastamento que o narrador quer manter das narrativas tradicionais. Mas ele quer o leitor acompanhando-o na nova forma de expressão que constrói. Para isso, retoma a debreagem enunciativa com a qual iniciou o parágrafo, convocando novamente o leitor a acompanhá-lo: "Saiamos do mar."

Essa segunda parte do conto refere-se à paixão de Luís Bastinhos por Marcelina, à inicial indiferença da moça pelos sentimentos do rapaz e à, finalmente, conquista da moça. Nesses capítulos - IV, V e VI, com exceção do início do capítulo IV, quando o narrador convida o leitor a acompanhar o deslocamento espacial ocorrido na narrativa -, as referências ao narratário materializadas na língua desaparecem. As ações transcorrem diante do leitor conduzidas pelo narrador até o final feliz tão ao gosto do leitor da época: o casamento selando a felicidade de Marcelina e Luís Bastinhos.

Machado de Assis busca, em "A chave", conquistar um leitor afeito à literatura romântica - quando emprega recursos dela característicos, como o sentimento amoroso garantindo a felicidade dos protagonistas - para reformular o seu gosto, tornando-o apto a ser seu leitor, capaz de apreciar a sua nova forma de narrar. Para isso empregou, nos três primeiros capítulos, referências diretas ao narratário que o convocaram à reflexão sobre a inconsistência dos recursos literários antigos; nos últimos três capítulos, a sua narrativa nada mais é do que o exemplo do discurso elaborado sem as marcas idealizadoras e melodramáticas que combatia. Ao apresentar as ações das personagens, realiza-o de forma direta e usa das atitudes e das falas das mesmas para criticar o modelo superficial de herói e heroína romântica, não mais empregando o diálogo com o narratário como recurso. É o que ocorre no trecho em que se revela a visão do Major Caldas sobre o casamento da filha:

Marcelina destruía-lhe as esperanças, reduzia-lhe a nada o projeto que ele acalentava, desde algum tempo - que era casar os dois [...]. E vai a moça e o destrói-lho. O major sentia-se velho, podia morrer, e quisera deixar a filha

\footnotetext{
5 Em Hamlet, de William Shakespeare, Ofélia, a personagem feminina, amada de Hamlet, enlouquecida com a morte do pai, afoga-se. (SHAKESPEARE, 1983).
} 
casada e bem casada. Onde achar melhor marido que Luís Bastinhos? (ASSIS, 2006, v. 2, p. 880).

A ideia de que a segurança feminina encontrava-se no casamento com um pretendente cuja moral fosse íntegra e tivesse boas condições financeiras, independentemente dos sentimentos que a mulher nutrisse pelo escolhido - no caso, Luís Bastinhos -, encontra a oposição dos anseios de Marcelina:

Também esta pensava na conveniência de casar e casar bem; mas nenhum homem lhe abrira deveras o coração. Quem sabe a fechadura não servia a nenhuma chave? Quem teria a verdadeira chave do coração de Marcelina? Ela chegou a supor que fosse um bacharel da vizinhança, mas esse casou dentro de algum tempo; depois desconfiara que a chave estivesse em poder de um oficial da marinha. Erro: o oficial não trazia chave consigo. Assim andou de ilusão em ilusão, e chegou à mesma tristeza do pai. Era fácil acabar com ela: era casar com o Bastinhos, o circunspecto, o melancólico, o taciturno. Bastinhos não tinha a chave! Equivalia a recebê-lo à porta sem lhe dar entrada ao coração. (ASSIS, 2006, v. 2, p. 880).

Também Marcelina vê o casamento bem realizado como fórmula de garantia da tranquilidade futura, mas assenta sua opinião na visão idealizadora desse consórcio: busca um pretendente que lhe desperte sentimentos arrebatadores, como aqueles representados nos romances românticos, acionados, ironicamente, pela chave do seu coração.

Têm-se, então, duas críticas. A primeira delas refere-se ao casamento realizado como um negócio entre duas partes que se beneficiam - a do noivo que, ao receber a esposa, assume também os seus bens materiais, e a da noiva que se vê reconhecida socialmente no seu papel de esposa e depois mãe, protegida pelo marido, que lhe proporciona condições materiais para uma vida tranquila. A segunda volta-se para a visão idealizadora feminina: a verdadeira felicidade une estabilidade financeira à emocional, que só pode ser alcançada com um esposo que seja a correspondência aos anseios da mulher.

A superficialidade das personagens do conto vai tomando forma a cada atitude ou pensamento apresentado. Novamente Marcelina é o alvo: seu espírito essencialmente voltado para devaneios é ridicularizado na passagem em que chega a lamentar a impossibilidade de se "encomendar" valsadores para a festa que o major organizava:

Começou por encomendar um rico vestido, elegeu costureira, adotou corte, coligiu adornos [...]. Joias, flores, fitas, leques, rendas, tudo the passou pelas mãos, e pela memória e pelos sonhos. Sim, a primeira quadrilha foi dançada em sonhos, com um belo cavalheiro húngaro, vestido à moda nacional, cópia de uma gravura da Ilustração Francesa, que ela vira de manhã. Acordada, lastimou sinceramente que não fosse possível ao pai encomendar, de envolta com os perus da ceia, um ou dois cavalheiros húngaros, - entre outros motivos porque eram valsadores intermináveis. $\mathrm{E}$ depois tão bonitos! (ASSIS, 2006, v. 2, p. 880).

Para acentuar a crítica a essa personalidade fútil de Marcelina, o narrador se vale, no final do conto, de uma observação de Pimentel marcadamente debochada: "O Pimentel, que serviu de padrinho ao noivo, disse-lhe na igreja, que em certos casos era melhor 
valsar que nadar, e que a verdadeira chave do coração de Marcelina não era a gratidão, mas a coreografia." (ASSIS, 2006, v.2, p. 885).

"A chave" traz, portanto, um esquema narrativo bipartido: nos três capítulos iniciais, há o emprego da metalinguagem, da preterição e do constante diálogo com o leitor para apontar-lhe a inadequação dos esquemas narrativos até então empregados e a necessidade de uma literatura elaborada objetivamente, sem modelos que a forjassem. Nos três últimos capítulos, tem-se a construção de um discurso que, embora aborde o tema da realização amorosa, critica os perfis de personagens que vigoravam como heróis ficcionais.

Em "Miss Dollar" e em "A chave", Machado de Assis elabora sua narrativa nos moldes românticos e consegue, assim, a adesão do seu leitor. Este, convocado a refletir sobre o desgaste das velhas fórmulas ficcionais, vê-se diante de uma nova forma de expressão literária que o narrador constrói e passa a assumir a sua função de parceiro na composição dessa nova literatura entremeada de referências metalinguísticas que partilham com o leitor as escolhas realizadas. Posicionado fixamente, o narrador apresenta os fatos, como se projetasse um filme e, atento aos seus significados, emite juízos e opiniões a respeito deles. Sua atenção está voltada para a construção de uma narrativa também provocadora de reflexão, de opinião crítica, mas que seja inovadora e fuja aos esquemas narrativos tradicionais. Para isso reelabora suas estruturas e busca uma nova forma de expressão compreendida por aqueles que, como ele, são capazes de perceber o artificialismo da literatura amalgamada nas estruturas préconcebidas do início do século XIX. Configura, então, um leitor apto a não só perceber o artificialismo dos modelos, mas também a criticá-los; junto com o narrador, constrói uma literatura moderna, livre dos procedimentos modelares.

\section{Referências bibliográficas}

ASSIS, Machado de. Obra completa. Rio de Janeiro: Nova Aguilar, 2006, 3 v.

BOSI, Alfredo. O enigma do olhar. São Paulo: Ática, 2003.

DIAS, Gonçalves. Poesia. São Paulo: Agir, 1969.

EL FAR, Alessandra. Páginas de sensação. Literatura popular e pornográfica no Rio de Janeiro (1870-1924). São Paulo: Companhia das Letras, 2004.

FAORO, Raimundo. Machado de Assis: a pirâmide e o trapézio. São Paulo: Companhia Editora Nacional, 1974. (Brasiliana, 356).

FIORIN, José Luiz. Em busca do sentido: estudos discursivos. São Paulo: 2008.

MATOS, Mário. Machado de Assis, contador de histórias. In: ASSIS, Machado de. Obra completa. Rio de Janeiro: Nova Aguilar, v. 2, 2006.

SHAKESPEARE, William. Hamlet. Edited by Bernard Lott. Singapore: Kiodo-Shing Loong Printing Industries Pte Ltda. 1983.

SOUSA, José Galante de. Bibliografia de Machado de Assis. Rio de Janeiro: Instituto Nacional do Livro, 1995. 